\title{
FILSAFAT ISLAM METAFISIKA MUHAMMAD IQBAL TENTANG TUHAN SEBAGAI EGO
}

\author{
Asep Kurniawan \\ IAIN Syekh Nurjati Cirebon
}

\begin{abstract}
Abstrak: Metafisika dalam filsafat Islam identik dengan Tuhan. Dia dicitrakan dalam berbagai macam pemikiran para filosof dengan mendasarkan pada argumen-argumen rasional dan filosofis. Iqbal menggunakan konsep Ego Absolut untuk menyebut Tuhan dengan segala konsekwensi logisnya, akan tetapi konsep Ego Absolut yang diusung oleh Iqbal ini seringkali dipahami sebagai panteisme. Padahal pada kesempatan tertentu Iqbal mengkritisi keras poin-poin penting panteisme. Iqbal berusaha menampilkan poros dimana Ego dan Ego Absolut dapat memenuhi tempatnya masing-masing dengan segala keunikan dan kekhasannya. Ego Absolut bagi Iqbal adalah hasrat dimana Ego terus-menerus berproses, bergerak dinamis, berkreasi dan memproduksi dalam skala sendiri. Hidup manusia ditentukan oleh aktivitas ego-Nya. Aktivitas ego pada dasarnya berupa aktivitas kehendak. Hidup adalah kehendak kreatif yang bertujuan dan bergerak menuju satu arah, yaitu Ego Absolut.
\end{abstract}

Kata Kunci: Metafisika, Ego, Tuhan

\section{A. Pendahuluan}

Kajian metafisika dalam sistimatika filsafat adalah kajian yang paling awal, sebelum epistimologi, dan aksiologi serta dijadikan sebagai landasan suatu pemikiran. Bahkan bagi para filosof klasik, filsafat identik dengan metafisika. Dalam filsafat Islam khususnya, kajian metafisika senantiasa terkait dengan kajian tentang eksistensi Tuhan (Allah SWT). Bahkan berbagai bangunan epistemologi yang digagas semata-mata hanya untuk satu hal; mengetahui tentang esensi Dzat yang Wujud. Memang kecenderungan pemikiran waktu itu menuntut bahwa Dzat yang Wujud mutlak harus dapat dipahami secara nalar.

Upaya para filosof membuat penalaran tentang Tuhan ini hanyalah satu dari sekian upaya untuk mengatakan bahwa Tuhan itu ada, menalar Tuhan serupa perjalanan panjang yang tak pernah selesai untuk terus diperjuangkan perjalannya. Setiap orang, siapapun mempunyai pemahaman tentang Tuhan dalam pikirannya masing-masing. Nalar yang ditujukan kepada Tuhan oleh para pemikir, filosof mempunyai implikasi logis yang berbeda-beda. 
Sebagaimana filosof-filosof terdahulu, Iqbal mendasari filsafat rekonstruksinya dengan metafisika ego dan kehendak manusia (will to power). Rekonstruksi baginya semacam metodologi yang membuka ruang bagi penyesuaian dengan perubahan demi terciptanya pemikiran yang sesuai dengan semangat zaman. Sementara kehendak untuk berbuat dan kekreatifan berpikir adalah kunci utama. Memang, Pemikiran manusia tidak pernah mencapai titik akhir. Maka dari itu, rekonstruksi adalah proses tanpa henti.

Iqbal mencoba membebaskan pemikiran-pemikiran filsafat yang hanya membatasi diri pada hal-hal yang nyata saja. Bagi Iqbal, pemikiran seharusnya tidak berhenti pada aspek-aspek lahiriah saja, melainkan mencoba lebih radikal masuk pada yang ada "dibalik" yang nyata.

Oleh karena itu, Iqbal merumuskan konsep metafisika yang kemudian menjadi petunjuk untuk memahami kerumitan pemikiran filosofisnya. Konsep metafisika Iqbal dimulai dengan mendiskusikan intuisi diri, kemudian intuisi realitas, dan langkah terakhir intuisi realitas absolut (Tuhan). Mengapa harus intuisi? Iya, intuisi adalah satu-satunya cara untuk membebaskan manusia dari "belenggu" positivistik yang tidak bisa dipungkiri dewasa ini memang menjadi mainstream di kebanyakan orang. Melalui intuisi lah hal-hal yang dianggap tidak ada menjadi ada. Intuisi juga mampu menyingkap hal-hal yang dianggap tertutup dan sulit dijangkau. Intuisi masuk pada diri manusia sebagai sebuah realitas yang dijangkau, tapi bukan oleh persepsi dan pikiran, akan tetapi hanya bisa dijangkau dengan hati dan perasaan.

Intuisi bukan milik akal atau intelek. Akal atau intelek hanya menjangkau dunia fenomena, yakni aspek realitas yang tampak dalam persepsi indrawi. Sedangkan hati membawa kita berhubungan dengan aspek realitas, bukan membuka persepsi indrawi. Dengan intuisi, objek pengetahuan dapat di pahami secara langsung. "Tuhan bukanlah sebuah entitas matematis atau sebuah sistem konsep yang saling berhubungan satu sama lain dan tidak berkaitan dengan pengalaman”. "Dia adalah suatu wujud objektif yang kongkret".

\section{B. Riwayat Singkat Muhammad Iqbal}

Nama Muhammad Iqbal di kalangan kaum muslimin pada masa sekarang ini bukanlah nama yang asing. Ia dikenal terutama sebagai seorang ulama besar yang 
berhasil mengintegrasikan kemampuan pemikiran dan kepenyairan sekaligus. Sosoknya memang fenomenal. Lebih dari siapa pun, Iqbal telah merekonstruksi sebuah bangunan filsafat Islam yang dapat menjadi bekal individu-individu muslim dalam mengantisipasi peradaban Barat yang materialistik ataupun tradisi Timur yang fatalistik. Jika diterapkan maka konsep-konsep filosofis Iqbal akan memiliki implikasi-implikasi kemanusiaan dan sosial yang luas. Tidaklah mengherankan jika orang menyebutnya sebagai pemikir yang penyair atau penyair yang pemikir (Javaid Rehman, 2005:15). Kenyataannya, baik sebagai penyair maupun sebagai pemikir, ia telah mewariskan suatu karya filsafat yang hingga kini masih sulit dicarikan bandingannya di kalangan pemikir muslim.

Riwayat hidup seseorang seringkali dianggap sebagai lampu penerang untuk mengetahui dan membaca pikiran seorang tokoh. Seperti halnya untuk memahami pikiran Muhammad Iqbal. Latar belakang kehidupannya tidak bisa diabaikan begitu saja. Sebagaimana yang diungkapkan oleh Sabri Tabrazi, pemeriksaan terhadap karya-karya Iqbal akan lebih berhasil dan imajinatif jika dilihat dari latar belakang sosial atau pengalaman hidupnya. Kebesaran nama Muhammad Iqbal dengan pemikirannya tidak dapat diragukan lagi khususnya bagi masyarakat Pakistan, Muhammad Iqbal tidak hanya sebagai seorang filosof namun juga seorang ahli hukum, pemikir politik, humanis, dan seorang yang visioner, serta seorang penyair dari Timur (Ayesha Jalal, 2000:565; Yahya, 2013:66; Naveed Shahzad Sheikh, 2007:83). Ia mendapat perhatian yang sangat luar biasa, dan hal tersebut terbukti dengan banyak penulis dan lembaga-lembaga yang mengkhususkan untuk membicarakan dan mengkaji pemikiran-pemikirannya secara mendalam dan juga tentang berbagai aspek-aspek yang berkaitan dengan diri Muhammad Iqbal.

Muhammad Iqbal lahir di Sialkot, perbatasan Punjab Barat sebuah kota peninggalan Dinasti Mughal India pada tanggal 22 Februari 1873 (Danusiri, 1996:3; Dhohan Effendi dan Abdullah Hadi, 1986:vii), dari keluarga yang tidak kaya. Sekarang berada di wilayah Pakistan. Leluhur Iqbal adalah keturunan keluarga Hindu dari kasta Brahmana dari sub kasta Sapru yang berasal dari daerah Kasymir. Mereka sudah memeluk Islam beberapa generasi sebelumnya (Annemarie Schimmel, 1963:35; Iqbal Singh Sevea, 2012:16). 
Ayah Iqbal bernama Syaikh Nur Muhammad, seorang pedagang muslim yang taat dan sufi. Karena kesalehan dan kecerdasannya, penjahit yang cukup berhasil ini dikenal memiliki perasaan mistis yang dalam serta rasa keingintahuan ilmiah yang tinggi. Tak heran, jika Nur Muhammad dijuluki kawan-kawannya dengan sebutan "Sang Filosof tanpa guru" (un parh falsafi).

Ibunya bernama Imam Bibi. Keluarganya dianggap terpandang dan taat beragama sehingga mempunyai pengaruh dalam pembentukan watak dan kepribadiannya (Salahuddin al-Nahlawi, 1995: 149; Harun Nasution, 1991:190). Ia membekali kelima anaknya, tiga putri dan dua putra, dengan pendidikan dasar dan disiplin keislaman yang kuat. Di bawah bimbingan kedua orangtuanya yang taat inilah Iqbal tumbuh dan dibesarkan. Kelak di kemudian hari, Iqbal sering berkata bahwa pandangan dunianya tidaklah dibangun melalui spekulasi filosofis, tetapi diwarisi dari kedua orangtuanya tersebut. Di masa kecil, Iqbal menerima pendidikan langsung dari orang tuanya terutama mengenai al-Qur'an. Pendidikan formalnya pertama kali diperoleh di Maktab, sebuah pendidikan klasik di Sialkot.

Ketika belajar di sekolah misi, Scotch Mission School Iqbal banyak diajari oleh Mir Hasan terutama tentang sastra Persia dan pengguasaan bahasa Arab. Pada tahun 1895 Iqbal melanjutkan studi ke Lahore (V.R. Taneja dan Taneja, S., 2004:151), salah satu kota di India yang menjadi pusat kebudayaan, pengetahuan dan seni. Di kota ini ia bergabung dengan perhimpunan sastrawan yang sering diundang musyara'ah, yakni pertemuan-pertemuan di mana para penyair membacakan sajaksajaknya. Ini merupakan tradisi yang masih berkembang di Pakistan dan India hingga kini.

Di kota Lahore ini, sambil melanjutkan pada Governmet College sampai mendapatkan gelar Sarjana Muda (B.A.) pada tahun 1897. Ia mendapat medali emas sebagai penghargaan karena prestasinya dalam ujian bahasa Arab. Disusul dengan gelar M.A. (Master of Arts) yang diperoleh pada tahun 1899. Ia mendapat medali emas pula dalam ujian magister ini. Di lembaga pendidikan ini Iqbal mendapat bimbingan filsafat Islam dari seorang orientalis yang bernama Thomas Arnold, yang mendorong Iqbal untuk melanjutkan studi di Inggris. Antara keduanya terjalin kedekatan melebihi hubungan guru dan murid, sebagaimana tertuang dalam sajaknya Bang-I Dara. Dengan dorongan dan dukungan dari Arnold, Iqbal menjadi terkenal 
sebagai salah satu pengajar yang berbakat dan penyair di Lahore. Sajak-sajaknya banyak diminati orang.

Pada tahun 1905 ia meneruskan studinya ke Universitas Cambridge, di sanalah ia memperdalam filsafat di bawah bimbingan seorang Neo-Hegelian, yaitu McTaggart dan James Ward (Danusiri, 1996:5) serta R.A. Nicholson, seorang spesialis dalam sufisme. Iqbal kemudian belajar di Heidilberg dan Munich. Di Munich ia menyelesaikan doktornya pada tahun 1908 dengan disertasi, The Development of Metaphysics in Persia di bawah bimbingan Prof. F. Hommel. (disertasi ini kemudian diterbitkan di London dalam bentuk buku, dan dihadiahkan Iqbal kepada gurunya, Sir Thomas Arnold).

Iqbal dipercaya memimpin Goverment College tahun 1908 setelah kembali dari Eropa. Ia juga mengajar filsafat, sastra Arab dan Inggris di universitas tersebut. Selama di Eropa Iqbal tidak pernah bosan menemui para ilmuwan untuk mengadakan berbagai perbincangan tentang persoalan-persoalan keilmuan dan kefilsafatan. Ia juga memperbincangkan Islam dan peradabannya. Di samping itu Iqbal memberikan ceramah dan berbagai kesempatan tentang Islam. Isi ceramahnya tersebut dipublikasikan dalam berbagai penerbitan surat kabar. Ternyata setelah menyaksikan langsung dan mengkaji kebudayaan Barat, ia tidak terpesona oleh gemerlapan dan daya pikat kebudayaan tersebut. Iqbal tetap concern pada budaya dan kepercayaannya.

Propesi lain sebagai pengacara ditekuni sampai tahun 1934 (Abdullah Wahab Azzam, 1985:27). Karir politik disandang sebagai anggota Dewan Legislatif di Punjab tahun 1926 - 1930 dan menjadi Dewan Legislatif merangkap jabatan sebagai presiden Liga Muslim. Menjadi delegasi Konfresensi Meja Bundar pada tahun 1931 dan 1932. Setahun kemudian ia dipercaya memegang jabatan presiden komite Kasymir, memimpin Konfrensi Muslim India. Sedangkan jabatan pemimpin Liga Muslim diserahkan ke Ali Jinnah (Danusiri, 1996:9).

Iqbal berpendapat bahwa muslim India sebagai minoritas perlu adanya penyatuan moral dan politik dalam satu kesatuan dan wilayah. Gagasan ini yang melahirkan semangat nasionalisme yang didasarkan atas kesamaan tersebut yang mengharuskan terbentuknya suatu komunikasi tersendiri dalam bentuk negara. Dalam pidatonya, Iqbal menekankan bahwa tidak seperti agama Kristen, Islam hadir 
dengan "konsep hukum" dengan "kepentingan sipil," dengan "cita-cita agamanya" yang dianggap tidak terpisahkan dari tatanan sosial. Oleh karena itu, pembangunan sebuah kebijakan mengenai garis nasional, adalah perpindahan prinsip solidaritas Islam (Naipaul, 1999:250). Gagasan ini direalisasikan bersama Ali Jinnah dengan membentuk negera tersendiri terpisah dari India dengan nama Pakistan (Esposito, 1987:220; Mukti Ali, 1996:182).

Sebagai seorang yang jenius, pesan-pesannya banyak menyentuh aspek kehidupan dan membawa kepada perubahan. Ia mewariskan kepada karya-karya monumental yang ditulis dalam berbagai bahasa; Arab, Persia, Urdu, dan Inggris. Diantara karyanya itu ialah sajak-sajak yang membuka jaman baru, seperti Syikwa dan Jawab al-Syikwa. Karya yang lain adalah Risalah Asrar-I-Khudi dan Rumuz-IBekhudi yang mesing-masing diterbitkan pada tahun 1915 dan 1918 (Maitre, 1992:16), Bang-i-dara (Genta Lonceng), Payam-i-Mashriq (Pesan Dari Timur), Jawaid Nama (Kitab Keabadian), Zarb-i-Kalim (Pukulan Tongkat Nabi Musa), Pas Cheh Bayad Kard Aye Aqwam-i-Sharq (Apakah Yang Akan Kau Lakukan Wahai Rakyat Timur?), Musafir Nama, Bal-i-Jibril (Sayap Jibril), Armughan-i-Hejaz (Hadiah Dari Hijaz), Development of Metaphyiscs in Persia, Lectures on the Reconstruction of Religius Thought in Islam Ilm al Iqtishad, a Contibution to the History of Muslim Philosopy, Zabur-i-'Ajam (Taman Rahasia Baru), dan Khusal Khan Khattak.

Sebagai seorang pemikir, tentu tidak dapat sepenuhnya dikatakan bahwa gagasan-gagasannya tersebut tanpa dipengaruhi oleh pemikir-pemikir sebelumnya. Iqbal hidup pada masa kekuasaan kolonial Inggris. Pada masa ini pemikiran kaum muslimin di anak benua India sangat dipengaruhi oleh seorang tokoh religius yaitu Syah Waliyullah Ad-Dahlawi dan Sayyid Ahmad Khan. Syah Ad-Dahlawi adalah Ahmad bin Abdurrahim bin Wajiduddin bin Mu'azzam bin Ahmad bin Muhammad bin Qawanuddin al-Dahlan.

Iqbal tutup usia pada tanggal 21 April 1938 akibat dari sakit yang dideritanya. Jenazahnya dimakamkan keesokan harinya di sebelah kiri tangga ke arah masjid Badsyahi, Lahore dengan iringan rakyat yang berjumlah besar dari berbagai golongan. Kematiannya diratapi dan memperoleh ucapan bela sungkawa dari para 
pemimpin besar dan tokoh-tokoh ahli pikir serta anggota pemerintahan (Danusiri, 1996:9).

\section{Metode Pemikiran Iqbal}

Dengan menyimak perjalanan pendidikannya dapat ditelusuri cara atau metode pemikiran Iqbal. Pada tahap awal dikenal sebagai pemikir (mistikus) muslim yang pantheistic (Danusiri, 1996:9) ditandai dengan konsepsinya tentang keindahan abadi (eternal beauty), yaitu konsep keindahan abadi, memandang Tuhan sebagai sesuatu zat yang indah, berdiri sendiri dan sekaligus menjelma seluruhnya dalam alam semesta. Keelokan alam semesta merupakan penjelmaan zat Tuhan (Sharif, 1973:100). Keindahan abadi adalah sumber, esensi dan idel segala sesuatu. Tuhan bersifat universal dan melingkupi seluruh alam semesta.

Pemikiran seperti itu tidak sulit dicari sumbernya yang pada dasarnya bersifat Platonis mengingat Plato juga menganggap Tuhan sebagai keindahan abadi sebagai alam universal yang mendahului segala sesuatu dan terwujud pada kesemuanya itu sebagai bentuk. Plato juga menganggap Dia sebagai ideal tujuan manusia (Syarif, 1994:28-29). Demikian pula, corak pemikiran ini sebagai pengaruh dari latar belakang masa kecil Iqbal yang lekat dengan budaya tasawuf dan pengajaran yang mendalam dari seorang guru, yaitu Mir Hasan yang sangat impresif baginya, terutama tentang budaya ketimuran dalam kontek kebudayaan Islam. Demikian pula dengan tokoh sufi Jalaluddin Rumi yang dianggap sebagai guru dan pembimbing spiritualnya (Annemarie Schimmel, 1963:42).

Tahap selanjutnya terjadi perubahan dalam pemikiran Iqbal sebagai akibat dari pendidikan Barat dan dialog kontinyuitas dengan banyak filosof. Sebagaimana dapat dilihat dari desertasinya yang mengkritik atas konsep peniadaan diri (fana) dalam sufisme serta pandangan terhadap sufisme.

Dari perjalanan pendidikan tersebut membawa kecenderungan yang unik dalam diri Iqbal, khususnya ketika ia akrab dengan filsafat dan pemikiran Barat dalam banyak hal berbeda dengan pemikiran Timur yang lebih dulu dimilikinya, menjadikan Iqbal sangat menguasai warisan intelektual Timur dan penghargaan terhadap disiplin ilmu Barat, pengetahuan yang dalam akan filsafat Barat. 
Dari keunikan tersebut membawa kepada metode berpikir yang bersifat sintesa, yaitu memadukan berbagai khazanah pemikiran Barat maupun Timur ke dalam satu gagasan dengan cara kritis dan selektif. Pertimbangannya, tidak semua yang datang dari Barat maupun Timur ditolak atau apa adanya. Terobosan baru pemikiran dan keterbukaan terhadap Barat dirangkum dalam The Reconstruction of Religious Thought in Islam (Iqbal, 1981). Ia menganjurkan untuk meninjau kembali keseluruhan sistem Islam tanpa memutuskan romantisme hubungan dengan peninggalan masa lalu. Pengasosiasian doktrin dan lembaga Islam tradisional ditafsirkan secara allogaris (kiasan) dengan rasionalisme Barat (Bonsard, 1986:323). Dari sini terlihat Iqbal berusaha menyodorkan kekayaan budaya Timur dalam konstelasi pemikiran Barat yang digelutinya semenjak melanjutkan belajarnya di Eropa.

Apa yang disebut sebagai Timur dan Barat pada dasarnya bukan hanya sekedar terminologi geografi, akan tetapi dari itu mencakup pula sejarah dan budaya. Sehingga terminologi sejarah berkaitan dengan kenyataan bahwa Barat yang ditandai dengan masyarakat komplek serta berada pada era industrialisasi tidak lepas dari perkembangan kenyataan Timur yang juga pernah mengalami kegemilangan masa lalu dalam ekonomi dan politik (Williams Yale, 1958:4). Sehinggga terminologi budaya berkaitan dengan corak pemikiran yang mewarnai tradisi kefilsafatan khususnya setelah munculnya gerakan renaisance dan aufklarung.

Metode diskursus yang dipilih Iqbal dibaca dengan intuisi. Dia tidak menginginkan pemberhalaan metode berfikir, sebagaimana ijtihad yang terpasung dengan sulitnya memenuhi persyaratan teoritis yang ditetapkan. Di sisi lain Iqbal berupaya untuk tidak terseret kepada arus pemikiran Barat yang cenderung atheis, karena sudut pandangnya yang materialistik.

Sebagai tokoh sintetis, Iqbal menekankan iman dan intuisi kadang-kadang lebih daripada akal dan kadang-kadang dengan mengorbankan akal tergantung kepada konteks di mana ia berbicara dan jenis kelompok yang diajak berbicara. Ada tiga posisi yang diambilnya dalam hubungan antara intuisi dan akal, yaitu (1) akal dan intuisi berbeda atau; (2) akal lebih rendah kedudukannya daripada intuisi atau hikmah: (3) di antara keduanya terdapat suatu hubungan organis dan dengan demikian keduanya saling membutuhkan. 
Ketika berbicara kepada Barat dan orang Islam yang sudah terbaratkan, ia cenderung untuk meminimalkan peran akal dan bahkan mencaci makinya. Adapun bila berbicara kepada kaum konservatif yang diinginkan agar menghargai rasionalisme dan keilmiahan Barat, ia cenderung menekankan akal. Oleh karena itu, pada diri Iqbal terdapat kesatuan yang lebih dalam antara tujuan dan cara mancapai tujuan ini dan kutukan terutamanya adalah terhadap pemikiran rasional yang tidak bersyarat dan tidak terarah, yang sebagian isinya merupakan kritikan terhadap westernisme, yaitu penerimaan mentah-mentah atas hasil rasionalisme Barat di kalangan masyarakat Islam (Fazlur Rahman, 1994:331). Tampaknya ia menyadari akan kegagalan Mustafa Kamal yang ingin “melompat” ke Eropa dengan menjadikan Turki sebagai negara yang sejajar dengan Eropa pada masa-masa berikutnya.

Keakraban dengan dunia pemikiran Barat menjadikannya sadar akan arah serta tujuan yang menurutnya tidak mampu memperoleh kesejatian. Iqbal merasakan pemikiran Barat yang materialistik serta kosong dari kearifan cinta sebagai musuh yang senantiasa menyelimutinya.

Pemikiran Barat memang berbahaya bagi dunia Islam akan tetapi ada hal yang memiliki ma'na positif, khususnya yang berkaitan dengan upaya mengembalikan vitalitas umat yang telah rapuh. Dalam kontek ini ia bermaksud menjelaskan akan hutang budi Eropa kepada dunia Islam. Apabila Eropa telah jauh lebih maju, maka sebenarnya hal tersebut merupakan dialektika sejarah di mana Eropa lahir dari proses dialog dengan Timur saat Turki mengalami banyak kemajuan di masa lalu.

Jadi Iqbal mengambil pemikir Barat tersebut bukan kerangka peniruan akan tetapi merupakan proses dialogis dalam menganalisa masalah-masalah pundamental, seperti Tuhan, alam dan manusia. Ia bisa menerima suatu pemikiran atau menolaknya dalam rangka menegakkan sistem pemikiran yang dicetuskannya.

Sementara itu, unsur pemikiran Timur Iqbal dapat diketahui lewat karya puisi dan prosanya, seperti Javit Namah. Dalam karya tersebut akan dijumpai penghargaannya terhadap mistik Timur (tasawuf) meskipun ia tidak setuju kepada tokoh-tokohnya yang dipandang tidak mampu menerima ilham segar dari dunia moderen. Dalam karyanya the Reconstruction of Religious Thought in Islam dia mengatakan.

The more genuine schools of Sufism have, no doubt, done good work in 
shaping and directing the evolution of religious experience in Islam but their latter-day, representatives, owing to their ignorance, of the modem mind, have become absolutely incapable of receiving any fresh inspiration from modern thought and experience. They are perpetuating methods which were created for generations possessing a cultural outlook differing, in important respect from our own (Iqbal, 1981:v).

\section{Telaah Historis Pemikiran tentang Tuhan Sebagai Ego}

Pemahaman Iqbal tentang Ketuhanan sebagai ego mengalami tiga tahap perkembangan, sesuai dengan perjalanan hidup yang dilaluinya dari tahap pencarian sampai ke tahap kematangan. Ketiga tahap itu adalah:

Pada masa pertama (dari tahun 1901 sampai sekitar tahun 1908). Iqbal mempercayai Tuhan sebagai keindahan abadi, yang ada tanpa tergantung dan mendahului segala sesuatu, bahkan Tuhan bersifat tajalli atau menampakkan diri dalam semuanya itu. Pada tahap inilah Iqbal dianggap menganut paham panteisme. Dia menyatakan dirinya di alam semesta ini, di langit dan di bumi, di matahari dan di bulan, di berbagai kondisi dan wilayah. Pada tahap ini Iqbal cenderung sebagai mistikus-panteistik, hal itu terlihat pada kekagumannya pada konsepsi mistik yang berkembang di wilayah Persia, lewat tokoh-tokoh tasawuf falsafi, seperti Ibn Arabi. Kita bisa melacak konsepsi ini melalui sebuah puisi yang ditulis oleh Iqbal dengan judul Zarathustra:

Cahaya ialah lautan, kegelapan hanyalah pantainya; tiada arus seperti diriku yang pernah ada dalam hatinya.

Dadaku riuh dengan ombak-ombak yang gelisah senantiasa; apa yang diperbuat arus kecuali merusak pantai lauatan?

Gambar yang tak berwarna, yang tak pernah kelihatan di mata insan, tak dapat dilukis kecuali dengan darah Ahriman.

Penampilan -itulah inti rahasia hidup ini, hidup ialah menguji daya pukul kita sendiri.

Diri menjadi lebih matang karena penderitaan

Sehingga diri itu pun merobek tabir-tabir yang menyelubungi Tuhan

Insan yang irfan Ilahi hanya melihat dirinya sendiri melalui Tuhan menyerukan Tuhan Esa, tersirap darah di badannya.

Tersirap darah di badan ialah kehormatan besar bagi cinta; isyarat, tongkat dan tali jerat - inilah pesta bagi cinta.

Di jalan cinta, apapun yang terbaik semata; maka sambutlah dengan baik keramahan tak manis dari Yang Tercinta!

Bukan mataku saja mendambakan penampilan diri Ilahi; adalah dosa memandang keindahan seorang diri? Kepedihan, kegairahan yang membakar dan kerinduan hati; 
Bersama-sama hendaknya dalam melihat, seorang diri dalam mencari.

Cinta dalam pengecilan diri ialah percakapan dengan Yang Esa; bila cinta maju ke depan memperlihatkan diri, jadilah ia raja!

Pengucilan diri dan penampilan (Iqbal, 2003:54-55).

Iqbal memakai dua kata sekaligus untuk menggambarkan Tuhan, pertama cahaya dan kedua laut. Untuk kata pertama yang digunakan adalah cahaya, dimana cahaya dipakai untuk menjelaskan keberadaan kegelapan. Kegelapan hanya ada jika cahaya wujud, ke-ada-aan kegelapan bergantung sepenuhnya kepada cahaya. Hal ini agak sedikit membingungkan, bagaimana kegelapan membutuhkan cahaya? Sedangkan kegelapan adalah ketiadaan cahaya? Iqbal dalam hal ini menyatakan bahwa tidak akan mungkin ada kegelapan jika tidak sumber cahaya, karena kegelapan hanya akan hadir jika tidak ada sumber cahaya - jadi yang hakiki bukanlah kegelapan akan tetapi cahaya itu sendiri.

Pemikiran Iqbal terpengaruh panteisme Ibnu Arabi atau wahdatul wujud (bersatunya kembali manusia dengan Tuhan). Tasawuf falsafi ini bersumber pada filsafat monoisme (Tuhan dan alam adalah tunggal) dengan cara emanasi atau al-faid (pancaran) dari Tuhan terjelmalah universum (alam semesta) yang serba aneka. Tasawuf panteisme Ibnu Arabi adalah tasawuf yang berpendapat bahwa hanya ada satu semata yaitu wujud Allah, bentuk jamak yang terlihat dari alam ini adalah ilusi yang menguasai keterbatasan akal budi. Ringkasnya wujud adalah satu tidak jamak.

Gagasan penenteisme Iqbal tentang hubungan manusia dengan Tuhan merupakan alternatif terhadap imanensi panteisme yang melenyapkan ego manusia maupun transendensi antromorfis yang menekankan kemahkuasaan Tuhan atas ciptaannya (Donny Gahral, 2003:65).

Keindahan Abadi adalah sumber, esensi, dan ideal segala sesuatu. Tuhan bersifat universal dan melingkupi segalanya seperti lautan, dan individu adalah seperti halnya setetes air atau seperti matahari dengan lilin. Pemikiran Iqbal yang demikian terpengaruh oleh Plotinus yang mengembangkan pemikiran Plato yang menganggap bahwa Tuhan sebagai Keindahan Abadi, sebagai alam universal yang mendahului segala sesuatu serta terwujud pada kesemuanya itu sebagai bentuk.

Platonis menganggap, Tuhan sebagai ideal tujuan manusia. Ia juga memisahkan cinta dari pengertian seks dan memberinya makna universal, konsep Platonis ini diambil alih oleh kaum skolastik muslim dan diintegrasikan ke dalam 
pantheisme oleh para mistikus pantheistis. Sehingga dapat dikatakan konsepsi Iqbal mengenai Tuhan pada masa awal ini tidak orisinil. Secara sederhana ia menunjukkan tentang apa yang ia terima sebagai warisan sejarah lewat kata-kata yang Indah. Ia menjadikan ide ketuhanan ini sebagai bahan puisi-puisinya dengan berbagai cara baru.

Walaupun ada pengaruh Platonis pada pemikiran Iqbal pada masa awal, ada perbedaan antara keduanya. Menurut Platonis, hidup pada dasarnya bersifat rasional, sedangkan bagi Iqbal, kehidupan bersifat sukarela sehingga harus ada kreatifitas untuk menjadikannya bermakna. Karena itulah, dalam pandangan Iqbal, dunia bukan sesuatu yang hanya dilihat dan dibentuk lagi lewat tindakan-tindakan nyata. Iqbal ingin memberikan gagasan keindahan yang berwawasan kreatif, dinamis dan aplikatif terhadap kehidupan dan lebih mengutamakan tindakan konkret daripada sekedar tindakan intelektual sebagai manifestasi perjuangan kehendak, hasrat dan cinta sang ego.

Masa kedua perkembangan pemikiran Iqbal bermula kira-kira tahun 1908-1920 M. kunci untuk memahami masa ini adalah perubahan sikap Iqbal kearah perbedaan yang ia tarik antara keindahan sebagaimana tampak pada segala sesuatu. Pada masa ini Iqbal tertarik kepada Rumi yang dijadikan sebagai pembimbing rohaninya. Sebagaimana telah dijelaskan sebelumnya bahwa Iqbal menyebut keindahan sebagai sesuatu yang kekal dan efisien serta kausalitas akhir dari segala cinta, gerakan dan keinginan. Tetapi pada masa kedua, sikap ini mengalami perubahan.

Pertama, suatu kesangsian dan kemudian berubah menjadi semacam psimisme yang menyelinap ke dalam dirinya mengenai sikap kekal dari keindahan dan efisiensinya serta kausalitas. Pada masa ini pemikirannya dibimbing oleh konsep tentang pribadi (self) yang dianggap sebagai pusat dinamis dari hasrat, upaya, aspirasi, usaha, keputusan, kekuatan dan aksi. Pribadi tidak eksis dalam waktu, melainkan waktulah yang merupakan dinamisme dari pribadi. Pribadi adalah aksi yang seperti pedang merambah jalannya dengan menaklukkan kesulitan, halangan dan rintangan. Waktu sebagai aksi adalah hidup dan hidup adalah pribadi karena itu waktu hidup dan pribadi ketiganya dibandingkan dengan pedang.

Yang disebut dengan dunia luar dengan segala macam kekayaannya yang menggairahkan termasuk ruang dan waktu serial dan apa yang disebut dengan dunia 
perasaan, ide-ide dan ideal-ideal keduanya adalah ciptaan pribadi mengikuti fichte dan ward, Iqbal menyatakan kepada kita bahwa pribadi menuntut dari dirinya sendiri sesuatu yang bukan pribadi demi kesempurnaannya sendiri. Dunia yang terindera adalah ciptaan pribadi. Karena itu segala keindahanm alam merupakan bentukan hasrat-hasrta kita sendiri. Hasrat menciptakan mereka,bukannya mereka yang mempunyai hasrat.

Tuhan sang hahekat terakhir adalah pribadi mutlak, ego tertinggi. Ia tidak lagi dianggap sebagai keindahan luar. Tuhan kini dianggap sebagai kemauan abadi dan keindahan disusutkan menjadi suatu sifat Tuhan, menjadi sebutan yangs ekarang mencakup nilai-nilai estetisdan nilai-nilai moral sekaligus. Disamping keindahan Tuhan, pada tahap ini keesaan tampak menunjukkan nilai pragmatis yang tinggi karena ia memberi kesatuan tujuan dan kekuatan pada individu, bangsa-bangsa dan manusia sebagai keseluruhan kekuatan yang mengikat, menciptakan hasrat yang tak kunjung padam, harapan dan aspirasi dan menghilangkan semua rasa gentar dan takut kepada yang bukan Tuhan.

Tuhan menyatakan dirinya bukan dalam dunia yang indera melainkan dalam pribadi terbatas, dan karena itu usaha mendekatkan diri padanya hanya akan dimungkinkan melalui pribadi. Dengan demikian mencari tuhan bersifat kondisional terhadap pencarian diri sendiri. Demikian pula Tuhan tidak bisa diperoleh dengan meminta-minta dan memohon semata-mata karena hal seperti itu menunjukkan kelemahan dan ketidak berdayaan. Mendekati Tuhan menurutnya harus konsisten dengan kekuatan dan kemauan sendiri. Ia harus menangkap Dia dengan cara sama seperti seorang pemburu menangkap buruannya. Tetapi Tuhan juga menginginkan diri-Nya tertangkap. Ia mencari manusia seperti manusia mencari-Nya. Dengan menemukan Tuhan seseorang tidak boleh membiarkan dirinya terserap ke dalam Tuhan dan menjadi tiada. Sebaliknya manusia harus menyerap Tuhan ke dalam dirinya, menyerap sebanyak mungkin sifat-sifat-Nya dan kemungkinan ini tidak terbatas. Dengan menyerap Tuhan ke dalam diri maka tumbuhlah ego. Ketika ego tumbuh menjadi super ego, ia naik ke tingkat wakil Tuhan. Tuhan bukan lagi dianggap sebagai Keindahan Luar, tetapi sebagai Kemauan Abadi, sementara Keindahan hanyalah sebagai sifat Tuhan disamping ke-Esa-an Tuhan. Karena itu, Tuhan itu menjadi asas kecintaan rohaniah tertinggi dari segala kehidupan. 
Makna hakiki perkataan cinta terkandung dalam kalimah La ilaha illa Allah (tiada tuhan selain Allah). Menurut Iqbal ialah cinta yang dapat mendorong seseorang tumbuh menjadi pribadi yang aktif dan dinamis, serta berkemampuan merasakan makna hidup dan arti keberadaan dirinya secara sungguh-sungguh. Cinta semacam ini bersemayam dalam diri seseorang yang teguh imannya dan siap mengurbankan hudupnya demi kepentingan agama dan kemanusiaan. Dalam hal ini Iqbal mengikuti guru kerohaniaanya Jalaluddin Rumi. Menurut Rumi arti semacam itu perasaan yang selalu akrab dengan pribadi nabi Muhammad dan ajaran al-Qur'an Iqbal menulis dengan indah dalam salah satu ghazal-nya (Abdul Hadi, 2000:59):

Titik tercelang bernama Diri (pribadi)

Ialah api hidup dibalik abu kita

Disebabkan cinta ia menjadi semakin kekal

Semakin cemerlang dan bersiar-sinar

Kilatan pedang cinta ialah sumber hayat

Tebing curam gemetar tersosot pandangnya

Cinta ilahi pada akhirnya menanamkan semangat ketuhanan dalam diri

Maka itu belajarlah mencintai dan dicintai

("Pribadi teguh oleh cinta" dalam Asrar-i Khudi)

Masa ketiga perkembangan mental dan pemikiran Iqbal dimulai sejak tahun 1920 hingga tahun 1938 dimana tahun wafatnya Iqbal. Masa ketiga ini dianggap sebagai masa kedewasaan dari pemikiran Iqbal itu sendiri. Jika masa kedua dapat dianggap sebagai masa pertumbuhan, maka pada masa ketiga ini dapat dianggap sebagai masa kedewasaan dan merupakan pengembangan menuju kematangan konsepsi tentang Ketuhanan. Tuhan adalah "hakikat sebagai suatu keseluruhan", dan hakikat sebagai suatu keseluruhan pada dasarnya bersifat spiritual, dalam arti suatu individu dan suatu ego. Untuk menjadi sempurna memerlukan suatu keadaan di mana tak ada bagian organisme yang terlepas dapat hidup secara terpisah. Dari bagian ini jelas bahwa individu yang sempurna merupakan unsur paling esensial dalam konsepsi al-Qur'an tentang Tuhan.

Ia dianggap sebagai ego karena seperti manusia, Dia adalah suatu prinsip kesatuan yang mengorganisasi, suatu paduan yang terikat satu sama lain yang berpangkal pada fitrah kehidupan organisme-Nya untuk suatu tujuan konstruktif. Ia adalah ego karena menanggapi refleksi kita. Karena ujian yang paling nyata pada suatu pribadi adalah apakah ia memberi tanggapan kepada panggilan pribadi yang 
lain. Tepatnya, Dia bersifat mutlak karena Dia meliputi segalanya, dan tidak ada sesuatu pun diluar Dia.

Ego mutlak tidaklah statis seperti alam semesta sebagaimana dalam pandangan Aristoteles. Dia adalah jiwa kreatif, kemauan dinamis atau tenaga hidup dan karena tidak ada sesuatu pun selain Dia yang bisa membatasi-Nya, maka sepenuhnya Dia merupakan jiwa kreatif yang bebas. Dia juga tidak terbatas. Tetapi sifat tidak terbatas-Nya bukanlah dalam arti keruangan, karena ketidak terbatasan ruang tidak bersifat mutlak. Ketidak terbatasan-Nya bersifat intensif bukan ekstensif dan mengandung kemungkinan aktivitas kreatif yang tidak terbatas. Tenaga hidup yang bebas dengan kemungkinan tak terbatas mempunyai arti bahwa Dia Maha Kuasa. Dengan demikian Ego terakhir adalah tenaga yang maha kuasa, gerak kedepan yang merdeka, suatu gerak kreatif.

Persoalan yang kemudian muncul dari gagasan yang diajukan Iqbal pada perjalanan intelektualnya yang terakhir adalah bagaimana mungkin Tuhan maha dari segala maha, yang kemahaannya tak terbatas dan maha mengetahuai dicitrakan sebagai ego? Sebagai sesuatu yang terbatas? Tentu saja citra yang diberikan oleh Iqbal pada Tuhan ini menimbulkan kontradiksi, karena Tuhan dicitrakan sebagai sesuatu yang terbatas, padahal Ia adalah sesuatu yang tak terbatas. Belum lagi persoalan yang akan muncul ketika membahas bagaimana hubungan Tuhan dengan manusia dan alam semesta.

\section{E. Tuhan sebagai Ego}

Konsep tentang hakikat ego atau individualitas merupakan konsep dasar dari filsafat Iqbal dan menjadi alas penopang keseluruhan struktur pemikiranpemikirannya. Perkataan ego atau self adalah mementingkan diri sendiri, arogansi, egoism, atau individualitas, merupakan suatu kesatuan yang riil atau nyata, adalah pusat dan landasan dari semua kehidupan. Dalam istilah filsafat Iqbal disebut Khudi. Ego adalah suatu kekuatan, yaitu "sebuah aku yang unik", kreatif dan senantiasa bergerak maju. Pribadi bukanlah lagi ada dalam waktu, tetapi waktu sendiri sudah menjadi dinamisme pribadi. Pribadi atau ego itu ialah action ialah hidup dan hidup ialah pribadi. 
Ia merupakan satu kebulatan yang jelas dan mempunyai arti, yang menjadi sentral dari segala struktur kehidupan manusia. Hidup manusia ditentukan oleh aktivitas ego-Nya. Aktivitas ego yang selalu mengarah kepada kesempurnaan suatu waktu akan mencapai perkembangannya yang tertinggi, yakni kesempurnaan di mana pada waktu itu dia akan merangkum samudera ketuhanan (khuda).

Ego adalah berarti Self-Reliance (Kepercayaan pada diri sendiri), Self-Respect (Rasa harga diri), Self Confidence (yakni percaya diri), Self Prevervation (penjagaan diri sendiri), bahkan Self Assertion (penegasan diri) (Bagus Takwin, 2003:148). Bila yang demikian itu perlu untuk kepentingan kehidupan dan kekuasaan agar tetap berpegang pada tujuan kebenaran, keadilan kewajiban dan lain-lain, bahkan dalam menghadapi kematian.

Menurut Iqbal, ego adalah pendorong daya kreatifitas pada setiap manusia, pusat dan landasan organisasi kehidupan manusia, seluruh cakupan pemikiran dan kesadaran tentang kehidupan. Dalam arti lain, ego merupakan sesuatu yang riil atau yang nyata, adalah pusat atau landasan dari semua kehidupan, merupakan suatu kehendak kreatif yang terarah secara rasional. Arti terarah secara rasional, menjelaskan hidup bukanlah suatu arus tak terbentuk, melainkan suatu prinsip kesatuan yang bersifat mengatur, suatu kegiatan yang sintesis yang melingkupi serta memusatkan kecendrungan-kecendrungan yang bercerai-berai dari organisme yang hidup kearah satu tujuan konstruktif.

Setiap manusia memiliki ego yang berbeda. Karenanya, hasil kreasi yang mereka ciptakan juga tidak sama. Menurut Iqbal aktivitas ego pada dasarnya berupa aktivitas kehendak. Hidup adalah kehendak kreatif yang bertujuan dan bergerak menuju satu arah, yaitu Ego absolute (Adian, 2001). Karena itu kehidupan manusia dalam keegoannya adalah perjuangan terus-menerus menaklukan rintangan dan halangan demi tercapainya ego tertinggi.

Iqbal menggunakan dasar ayat al-Qur'an terkait gagasannya ini yaitu surah alIkhlas;

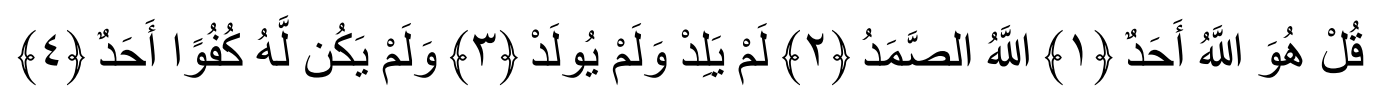

Katakanlah: Dia-lah Allah, yang Maha Esa. Allah adalah Tuhan yang bergantung kepada-Nya segala sesuatu. Dia tiada beranak dan tidak pula diperanakkan, Dan tidak ada seorangpun yang setara dengan Dia. 
Juga pada pada surah al- Baqarah ayat 186:

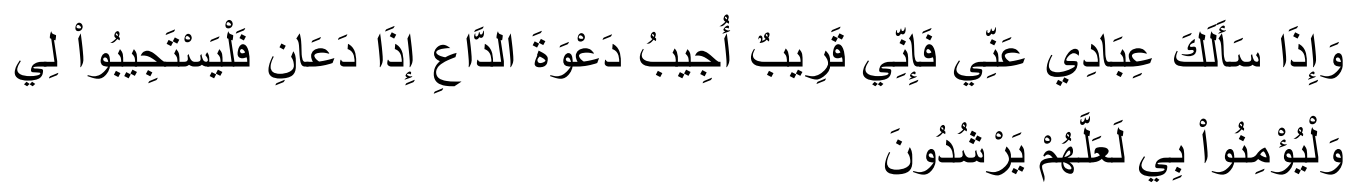

Dan apabila hamba-hamba-Ku bertanya kepadamu tentang aku, Maka (jawablah), bahwasanya Aku adalah dekat. Aku mengabulkan permohonan orang yang berdoa apabila ia memohon kepada-Ku, Maka hendaklah mereka itu memenuhi (segala perintah-Ku) dan hendaklah mereka beriman kepada-Ku, agar mereka selalu berada dalam kebenaran.

Dalam hal ini, karena rintangan yang terbesar adalah benda atau alam, manusia harus menumbuhkan instrument-instrument tertentu dalam dirinya, misalnya daya indra, daya nalar dan lainnya yang membantunya menyesuaikan penghalangpenghalangnya. Selain itu manusia harus terus-menerus menciptakan hasrat dan citacita dalam kilatan cinta ('isyq), keberanian dan kreatifitas yang merupakan esensi dari keteguhan pribadi. Keindahan tidak lain adalah bentuk dari ekspresi kehendak, hasrat, cinta itu dalam mencapai ego mutlak tersebut (Khudori Soleh, 2004:303). Tujuan tersebut tidak ditetapkan oleh hukum-hukum sejarah dan takdir dikarenakan manusia berkehendak bebas dan berkreatif. Hal inilah yang membuat manusia memiliki dirinya, manusia memiliki ego. Ego yang bersifat bebas unifed dan immoratal dan dapat diketahui secara pasti, tidak sekedar pengandaian logis. Karena itulah, kemudian dikenal bahwa filsafat Iqbal terpusat pada ego atau "self hood".

Tuhan menurut Iqbal memberikan kebebasan penuh kepada setiap ego itu. Untuk berkreasi dan berekspresi. Iqbal sendiri menggambarkan Tuhan sebagai ego absolut yang paling berdaya kreatifitas sempurna. Tuhan adalah keindahan Abadi dan penyebab gerak segala sesuatu. Kekuatan pada benda-benda, daya tumbuh pada tanaman, naluri pada binatang buas dan kemauan pada manusia hanyalah sekedar bentuk daya tarik ini, cinta untuk Tuhan ini. Oleh karena itu, Keindahan Abadi adalah sumber, essensi dan ideal segala sesuatu. Tuhan bersifat universal dan melingkupi segala sesuatu seperti lautan, dan individu adalah seperti halnya setetes air. Demikianlah, Tuhan adalah seperti matahari dan individu adalah seperti lilin, dan nyala lilin hilang di tengah cahaya. Seperti balon atau bunga api, kehidupan ini bersifat sementara tidak hanya itu bahkan keseluruhan eksistensi adalah suatu yang tidak kekal. 
Dalam pemikiran filsafat, gagasan Iqbal tersebut disebut sebagai Estetika Vitalisme, yakni bahwa keindahan merupakan ekspresi ego-ego dalam kerangka prinsip-prinsip universal dari suatu dorongan hidup yang berdenyut di balik kehidupan sehingga harus juga memberikan kehidupan baru atau memberikan semangat hidup bagi lingkungannya. Tidak hanya sampai disitu, bahkan lebih jauh lagi, Iqbal menginginkan bahwa ego-ego tersebut harus mampu memberikan "hal baru" dalam kehidupan. Dengan melawan sifat-sifat Tuhan dalam penyempurnaan kualitas dirinya, manusia harus mampu menjadi "saingan" Tuhan. Disinilah hakikat pribadi dan kebanggaan manusia di hadapan Tuhan (Khudori Soleh, 2004:3006-307).

Ego adalah usaha menjadikan diri Individu yang selalu diliputi sifat-sifat Tuhan yang sempurna. Tuhan menjelmakan sifat-sifatnya bukanlah di alam ini dengan sempurna tetapi pada para pribadi sehingga mendekati Tuhan berarti menumbuhkan sifat-sifat-Nya dalam diri, yang sebenarnya sesuai dengan hadist Rasullah s.a.w: Takhallaqu bi akhlaqi'llah, tumbuhkanlah dalam dirimu sifat-sifat Allah. Ini terlihat ketika Iqbal melukiskan kejayaan pribadi dan jalan hidup Nabi Muhammad saw. Hal ini terlihat dalam tafsir sajaknya bahwa untuk perkembangan sewajarnya dari setiap muslim dirindukannya suatu masyarakat menurut acuan Islam, dan setiap muslim yang berusaha akan menjadikan dirinya individu yang sempurna dan turut membangun kehidupan yang islami di bumi ini.

Syarat-syarat untuk membangun kehidupan islami itu dilukiskan Iqbal dalam kumpulan syairnya yang kedua, yakni: Rumuz -i- bekhudi, yang diterbitkan sesudah Asrar -i-khudi. Dalam buku kumpulan syair Rumuz -i- bekhudi itu Iqbal melukiskan bahwa orang yang dapat menafikan dirinya sendiri dalam masyarakat, membayangkan yang silam dan yang akan datang sebagai suatu satuan di dalam cermin, dapatlah dia mengatasi sang ajal dan masuk ke dalam hidup keislaman yang bersifat abadi dan tidak terbatas. Diantara acara-acara terpenting yang didendangkan Iqbal ialah: asal-usul masyarakat, Kemimpinan Tuhan pada manusia dengan perantaraan para nabi. Pembentukan pusat-pusat hidup kolektif dan nilai sejarah sebagai faktor penting untuk menetapkan tanda tersendiri dalam diri suatu bangsa.

Mencari Tuhan bukanlah dengan jalan merendah-rendahkan diri atau memintaminta, tetapi dengan himmah tenaga yang berkobar-kobar menjelmakan sifat-sifat uluhiyyah (ketuhanan) dalam diri kita dan kepada masyarakat ramai. Tegasnya 
mendekati Tuhan ialah menyempurnakan diri pribadi insan, memperkuat iradah atau kemauannya.

Maka menurut Iqbal pribadi sejati adalah bukan yang menguasai alam benda tetapi pribadi yang dilingkupi Tuhan ke dalam egonya sendiri. Maka sifat dan pikiran pribadi atau ego ialah tidak terikat oleh ruang sebagaimana halnya dengan tubuh hanyalah lanjutan masa mengenai kepribadian dan kepribadian pada asasnya tersendiri dan unik.

Sedangkan cita tentang pribadi itu memberikan kepada kita ukuran yang sebenarnya, diselesaikannya soal buruk dan baik. Hal-hal yang memperkuat pribadi bagi Iqbal ialah:'isyq-o-muhabbat, yakni cinta kasih, faqr yang artinya sikap tak peduli terhadap apa yang disediakan oleh dunia ini sebab bercita-cita yang lebih agung lagi, keberanian, sikap tenggang rasa (toleransi), kasb-i-halal yang sebaikbaiknya terjalin dengan hidup dengan usaha dan nafkah yang sah, dan mengerjakan kerja kreatif. Jika keenam kreatifitas ini dilakukan manusia maka egonya menjadi pribadi sempurna dan mencontoh sifat-sifat Tuhan dalam ego-Nya.

\section{F. Penutup}

Dengan konsep filsafat metafisika ego-Nya, memandang hakiki Tuhan dan pengetahuan benda-benda. Tentang Tuhan di mata iqbal sendiri Tuhan abadi dan bersifat keseluruhan ada-Nya meliputi segalanya alam semesta. Iqbal menafsirkan bahwa setiap manusia memiliki kehendak bebas (free will) untuk menentukan dirinya sendiri dengan demikian harus berani berkreasi dan mandiri dalam berfikir. Iqbal telah berusaha secara serius terhadap perumusan kembali tentang pemikiran metafisika ego ketuhanan dalam Islam. Ia menggambarkan Tuhan sebagai ego absolut yang paling berdaya kreatifitas sempurna, bersifat bebas unifed dan immoratal. Hidup manusia ditentukan oleh aktivitas ego-Nya. Hidup adalah kehendak kreatif yang bertujuan dan bergerak menuju satu arah, yaitu Ego absolute.

\section{DAFTAR PUSTAKA}

Adian, Donny Grahal. 2001. Matinya Metafisika Barat. Depok: Komunitas Bambu Ali, Mukti. 1996. Alam Pikiran Islam Moderen di India dan Pakistan. Bandung: Mizan. Azzzam, Abdul Wahab. 1985. Iqbal: Siratuhu wa Falsafatuhu. Diterjemahkan oleh Ahmad Rafi Usman dengan judul Filsafat dan Puisi Iqbal. Bandung: Pustaka. 
Bagus Takwin. 2003. Filsafat Timur: Pengantar ke Pemikiran-Pemikiran Timur. Yogyakarta: Jalasutra.

Bonsard, Marcel A. L. 1986. Humanisme de I Islam. Diterjemahkan oleh H.M. Rasyidi dengan judul Humanisme dalam Islam. Jakarta: Bulan Bintang.

Danusiri. 1996. Epistimologi dalam Tasawuf Iqbal. Yogyakarta: Pustaka Pelajar.

Effendi, Dhohan dan Abdullah Hadi W.M., (ed.). 1986. Iqbal: Pemikiran Sosial Islam dan Sajak-sajaknya. Jakarta: P.T. Panja Simponi

Esposito, John L. 1987. Dinamika Kebangunan Islam. Diterjemahkan oleh Bakri Siregar. Jakarta: Rajawali Press.

Gahral, Donny. 2003. Muhammad Iqbal. Jakarta: Teraju.

Hadi, Abdul. 2000. Islam Cakrawala Estetik dan Budaya. Jakarta: Pustaka Firdaus.

Iqbal, Sir Muhammad. 1981. The Reconstruction of Religious Thought in Islam. New Delhi: Nusrat Ali for Kitab Baden.

Iqbal, Javid Namah, terj. Hartojo Andangdjaja (Bandung: Pustaka jaya, 2003) hal. 5455.

Jalal, Ayesha. 2000. Self and Sovereignty: Individual and Community in South Asian Islam Since 1850. United Kingdom: Routledge.

Maitre, Miss Luce Claude. 1992. Introduction to the Thought of Iqbal. Diterjemahkan oleh Djohan Efendi dengan judul Pengantar ke Pemikiran Iqbal. Bandung: Mizan.

Nahlawi, Salahuddin al-. 1995. "Mohammad Iqbal: Western Civilazation" dalam Saiful Muzani, et al, (ed). Studia Islamika: Journal for Islamic Studies. Jakarta: IAIN Syarif Hidayatullah.

Naipaul, V. S. 1999. Beyond Belief: Islamic Excursions Among the Converted Peoples. New York: Random House.Nasution, Harun. 1991. Pembaharuan dalam Islam: Sejarah Pemikiran dan Gerakan. Jakarta: Bulan Bintang.

Rahman, Fazlur. 1994. Islam. Diterjemahkan oleh Ahsin Muhammad dengan judul yang sama. Bandung: Pustaka.

Rehman, Javaid. 2005. Islamic State Practices, International Law and the Threat from Terrorism: A Critique of the 'Clash of Civilizations' in the New World Order. London, United Kingdom: Bloomsbury Publishing.

Sevea, Iqbal Singh. 2012. The Political Philosophy of Muhammad Iqbal: Islam and Nationalism in Late Colonial India. Cambridge: Cambridge University Press

Schimmel, Annemarie. 1963. Gabriel's Wing: Study into the Religious Ideas of Sir Muhammad Iqbal. Leiden: E.J. Brill

Sharif, M.M. 1973. "Iqbal's Conception of God”, dalam M. Raziuddin Shiddiq, (ed.). Iqbal as a Thikers. Lahore: S.H. Muhammad Ashraf.

1994. About Iqbal and his Thought. Diterjemahkan oleh Yusuf Jamil dengan judul Iqbal tentang Tuhan dan Keindahan. Bandung: Mizan.

Sheikh, Naveed Shahzad. 2007. The New Politics of Islam: Pan-Islamic Foreign Policy in a World of States. Abingdon, United Kingdom: Routledge. 
Soleh, Khudori. 2004. Wacana Baru Filsafat Islam Yogyakarta: Pustaka Pelajar.

Taneja, V.R; Taneja, S. 2004. Educational Thinkers. London: Atlantic Publisher.

Yahya, MD. 2013. "Traditions of Patriotism in Urdu Poetry: A Critical Study with Special Reference to the Poet of the East Allama Iqbal and His Poetry", dalam Journal of Contemporary Research. Volume1, Issue 2. Juli 2013. 66-76.

Yale, Williams. 1958. The Near East. New York: The University of Michigan Press. 